\title{
Fibrin Rich in Leukocytes and Platelets (L-PRF) and Bisphosphonate-Induced Osteonecrosis: We Need to Advertise Now
}

\author{
Maria De Fatima Faria1, Eric Lucas Dos Santos Cabral'2, Wilkson Ricardo Silva Castro², \\ Davidson Rogério De Medeiros Florentino², João Florêncio Da Costa Junior², \\ Ricardo Pires De Souza², Fausto Pierdoná Guzen³, Francisco Irochima Pinheiro3, \\ Amália Cinthia Meneses Rêgo ${ }^{3}$, Irami Araújo-Filho ${ }^{3}$
}

\author{
1Post Graduate Program in Biotechnology, Health School, Potiguar University (UnP), Natal-RN, Brazil \\ 2Master's Degree in Production Engineering by the Graduate Program in Production Engineering at \\ 2UFRN / Natal-RN, Brazil \\ ${ }^{3}$ Full Professor of the Postgraduate Program in Biotechnology, Potiguar University \\ ${ }^{3}$ (UnP)-Laureate International Universities -Natal, Rio Grande do Norte, Brazil
}

\begin{abstract}
How to cite this paper: Maria De Fatima Faria | Eric Lucas Dos Santos Cabral | Wilkson Ricardo Silva Castro | Davidson Rogério De Medeiros Florentino | João Florêncio Da Costa Junior | Ricardo Pires De Souza | Fausto Pierdoná Guzen | Francisco Irochima Pinheiro | Amália Cinthia Meneses Rêgo | Irami AraújoFilho "Fibrin Rich in Leukocytes and Platelets (L-PRF) and BisphosphonateInduced Osteonecrosis: We Need to Advertise Now" Published in International Journal of Trend in Scientific Research and Development (ijtsrd), ISSN: 24566470, Volume-3 | Issue-3, April 2019, pp.883-889, URL: https://www.ijtsrd.c om/papers/ijtsrd23 040.pdf

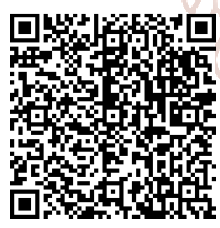
IITSRD23040
\end{abstract}

Copyright (C) 2019 by author(s) and International Journal of Trend in Scientific Research and Development Journal. This is an Open Access article distributed under the terms of the Creative Commons

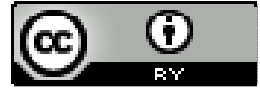

Attribution License (CC BY 4.0) (http://creativecommons.org/licenses/ by/4.0)

\section{ABSTRACT}

The American Association of Oral and Maxillofacial Surgeons (AAOMS) reported in 2004 a new pathology that causes osteonecrosis in the Maxillomandibular complex. The condition was named Bisphosphonate-related osteonecrosis of the jaw (BRONJ), and later renamed by medication related to jaw osteonecrosis due to the appearance of severe alveolar bone loss in the Maxillomandibular complex resulting from the use of different drugs other than Bisphosphonates. Odontology, especially oral surgery, a field concerned with new biotechnologies, has been introducing innovations in tissue engineering. Oro-maxillofacial reconstruction is of great interest to current oral and maxillofacial surgeons, as part of the search for strategies in bioengineering and biomaterials, a major promoter of bio-dental research in our times. In order to verify the scientific evidences to analyse the effectiveness of leukocyte and platelet rich fibrin (LPRF) on bone neoformation in Maxillomandibular complex's surgical procedures, a search for qualified articles was conducted in the Medline (PubMed), Embase and Cochrane Central Register of Controlled Trials databases. The works analysed were published from 2013 to 2018. This review concludes that the use of platelet rich fibrin (L-PRF) is significant in the complete healing of the lesion in short postoperative periods and in the resolution of the treatments, reducing the need for postoperative re-interventions, resulting in lower morbidity for the patients.

KEYWORDS: leukocyte and platelet-rich fibrin, L-PRF, platelet-rich fibrin, bisphosphonate-associated osteonecrosis of the jaw, bisphosphonate-associated osteonecrosis, bisphosphonate related osteonecrosis of the jaw.

\section{Introduction}

Bisphosphonates are synthetic pharmacological substances that have high affinity for hydroxyapatite, analogous to pyrophosphates - a substance present in the bone matrix naturally - which act as anti-remodelling agents, used for treatments of metabolic bone diseases such as cancerous complications of bone metastases and in the prevention of osteoporosis $^{1,2}$. They are medicament widely prescribed and widely used for the treatment of osteoporosis and other chronical bone deceases; these synthetic agents have great affinity for calcium, acting on osteoclasts and osteoblasts, decreasing bone remodelling and inhibiting mediators of inflammation, decreasing bone turnover, altering the mechanism of bone tissue $\mathrm{e}^{3,4}$.

Bisphosphonate-related osteonecrosis of the jaw (BRONJ) is a complication caused by bisphosphonate therapy, which causes progressive bone destruction in the maxillofacial region ${ }^{5}$. The lesion is characterized by necrotic, avascular 
bone in the maxillofacial area, exposed or not to the buccal environment and persists for more than eight weeks in patients who did not present oral cancer or history of previous radiation therapies in the craniofacial region6.

The first cases of BRONJ were described by Marx in 2003, detailing 36 cases of bone exposure in the oral cavity in patients undergoing intravenous use with bisphosphonates in cancer therapy7; whereas in 2004, Ruggiero observed 63 cases of Osteonecrosis in the oral cavity with a history of chronic therapy with bisphosphonates. ${ }^{8}$ In 2006, several studies on BRONJ were reported ${ }^{9-11}$; since then several professionals identified and demonstrated how to manage the illness, based on their empirical experience and opinions $^{12-14}$.

According to American Association of Oral and Maxillofacial Surgeons, Position Paper on Bisphosphonate-Related Osteonecrosis of the Jaw, patients must be diagnosed as suffering from BRONJ if all the following conditions are present: 1) current or previous treatment with bisphosphonates; 2) bone exposed in the maxillofacial region, persistent for more than 8 weeks; and 3) no history of radiation therapy for the jaw region. BRONJ may be asymptomatic or exhibit symptoms such as pain, oedema, dental loss and altered sensation (Figure 1) ${ }^{15,16}$.

Besides bisphosphonates, other medicaments have been associated with Osteonecrosis in the maxillofacial region, such as denosumab, bevacizumab, cabozantinib and sunitinib (AAOMS, 2004). As a result of that, the condition was then renamed Medication-related osteonecrosis of the jaw (MRONJ) ${ }^{15}$.

MRONJ, as a challenging complication related to the use of antiresorptive drugs, does not affect only the alveolar bone of the oral cavity, but also has presented oral mucosal loss in most patients with the disease, thus suggesting an adverse effect on the soft tissues of the oral cavity ${ }^{17}$.

MRONJ affects dramatically the patients' quality of life, thus justifying to actively seeking prevention in the risky cases ${ }^{18}$. Several clinical guidelines recommend discontinuation for a period of 3 months before being submitted to dental surgical procedures to patients who use these drugs as systemic therapy ${ }^{14}$. However, other guidelines do not concur that the interruption for a short period of time of antiresorptive medications should decrease the risk of Osteonecrosis in maxillofacial region ${ }^{19}$.

Factors associated with increased MRONJ risk are the following: (a) the potency of the drug used, (b) prolonged use of the drug, (c) advanced age and (d) history of inflammatory disease in the oral cavity ${ }^{14}$. Ruggiero suggests that patients who require antireabsorption therapy should undergo a thorough review with a specific health care provider to assess their oral health for dental extractions or other oral surgical procedures prior to initiating bisphosphonate or similar therapy ${ }^{14-16}$.

To date, there is still no standard protocol for MRONJ surgical treatment, which has been done empirically according to the clinical and radiographic evaluation of each professional $^{20,21}$.

Conventional treatment is indicated for cases in the initial stages of the disease (Stage I). As for severe cases (Stage II,
III), surgery for resection of necrotic tissue and curettage is necessary. The AAOMS classification of $\mathrm{MRONJ}^{22,23}$ is as follows: Stage 1- Exposed and necrotic bone or fistula, asymptomatic patient with or without infection; Stage II Exposed and necrotic bone or fistulas associated with infection and pain, erythema in exposed bone region, with or without draining purulent secretion; Stage III - Exposed necrotic bone or fistula extending beyond the alveolar bone region and patient with pain, infection, and presence of one or more of the complications: pathological fracture, extra oral fistula, oro-antral or oro-nasal communication, osteolysis extending on the edge of the mandible or maxillary sinus (Figure 1).

Complementary treatments to surgerie - such as laser therapy, Ozonotherapy, hyperbaric oxygen therapy and autologous platelet concentrates - have been used to improve the healing of bone and epithelial tissue, reducing lesion recurrence ${ }^{21-24}$.

In 1998 Marx reported for the first time in history the use of platelet rich plasma (PRP) to promote improvement in wound healing in the maxillofacial region ${ }^{25}$. Since then, several clinical reports have related the efficacy of the use of autologous platelet concentrates for the treatment and prevention of MRONJ ${ }^{26-28}$. Plasma platelet risk (PRP) showed promising results in the acceleration of soft tissue healing and bone regeneration in several studies in which the use of platelet concentrates has become popular ${ }^{29-31}$.

Faced with such evidence, Choukroun et al., developed the Fibrin Rich in Leukocytes and Platelets (L-PRF), the second generation of platelet immune concentrate, which represents a new biotechnology to stimulate bone regeneration and speed up the healing of soft tissues, because the PRF membrane forms a physical barrier against microorganisms, thus protecting the surgical wound from further contamination of the surgical site ${ }^{32,33}$.

Researchers use the term PRF, however L-PRF is more appropriate because it highlights the importance of leukocytes within the platelet concentrate ${ }^{34}$. Fibrin rich in leukocytes and platelets (L-PRF) is the most recently used method of blood concentrates. It allows a natural coagulation process without addition of chemical agents, unlike the process to obtain $\mathrm{PRP}^{35}$.

Furthermore, unlike PRP, L-PRF dissolves slowly after use, keeping it stable for a longer period of time, preserving the fibrin mesh, allowing longer cytokine life and a higher concentration of platelets, leukocytes, circulating stem cells incorporated within the physiological matrix of fibrin. Consequently, growth factors are allowed to be released more slowly at the surgical site, persisting for a longer time during wound cicatrisation, from 7 to 28 days $^{35,36}$.

L-PRF has been described as "an immune and platelet concentrate in a single fibrin membrane, containing all constituents of the blood sample favourable for healing and immunity"37.

The leukocytes present within L-PRF play a role as an antiinfective action, immunological regulation, ability to produce a great number of vascular endothelial growth factors (VEGF), which has caught the interest and curiosity of researchers ${ }^{38,39}$ 
Taking into account the above considerations, it is important to further research whether L-PRF is effective in the treatment of MRONJ, stimulating the natural biological process of healing and tissue regeneration, compared to previous procedures related in the current literature. Consequently, the present article endeavours to review the relevant literature in order to evaluate the effect of L-PRF as a new biotechnology for the treatment of MRONJ.

\section{Methods}

A digital search was performed for relevant work in the Cochrane-Library (Cochrane), MEDLINE/Pub Med, Scopus and Embase databases, with no date or language limitation, articles dating from the year 2013 to September of 2018, related to the key words: "leukocyte and platelet-rich fibrin, $L-P R F$, platelet-rich fibrin, bisphosphonate-associated osteonecrosis of the jaw, bisphosphonate-associated osteonecrosis, bisphosphonate related osteonecrosis of the jaw".

Also, the search for new works was carried out in the references section of the selected articles (cross reference). The last article search was conducted in September 2018.

The search was limited to articles written in English. The studies that fulfilled the inclusion criteria were evaluated for the methodological quality with criterion methodology and the use of the JADAD scale due to the heterogeneity of the studies (Table 1). To be included, the studies had to report the results of surgical procedures performed in patients with MRONJ therapies, to whom L-PRF was the complementary therapy chosen for adjuvant use. Only studies that involved human patients were included in the review.

There were limitations regarding the size of the sample. The studies reported which anti-resorptive medications were used; stages of the disease and affected areas in the maxillofacial region. The resolution of the treatments had clear definitions to consider success of the procedure performed. Exclusion criteria were history of radiation therapy to the head and neck, oral cancer and treatments performed with other blood concentrates other than L-PRF or PRF.

The process of searching and sorting the articles was done by analysing the title and summary of each study. Those studies that did not meet the inclusion criteria of this review were excluded. The articles pertaining to the inclusion criteria were examined by two independent researchers, with a third party in case of disagreement regarding the inclusion of studies in the present review. Despite the inheritance found about the type of studies, those who addressed the topic directly and in a clear and concise manner were selected for the data analysis and included in the research.

The following data, when present, were extracted from the included studies: author / date, related disease, study followup period, number of patients treated, average age and gender, type of medication used, time of therapy, route of administration, type of surgical procedure performed, follow-up and resolution.

All patients in the articles studied were on therapy or would have been treated with antireabsorbable agents, had exposed bone in the maxillofacial region persistent for more than 8 weeks and confirmed destruction of bone lesion radio graphically or clinically, which required surgical intervention of accordance with AAOMS.

Stages of the lesion were verified according to the AAOMS clinical classification of MRONJ: Stage I: exposed and necrotic bone or fistula, asymptomatic patient with or without infection; Stage II: Necrotic and exposed bone or fistulas associated with infection and pain, erythema in exposed bone region, with or without draining purulent secretion; Stage III: Necrotic and exposed bone or fistula extending beyond the alveolar bone region and patient with pain, infection, and presence of one or more of the complications: pathological fracture, extra oral fistula, oro-antral or oronasal communication, osteolysis extending into the border of the mandible or maxillary sinus ${ }^{11}$.

\section{Results}

Our literature review covered 14 studies in a total of 303 patients who had stage II or III of MRNOJ - according to AAOMS classification - with necrotic bone exposure for more than 8 weeks and history of antireabsorption drug treatment, divided into maxilla and mandibles, women and men, average age of 60 years, who underwent bone necrotic tissue removal surgery, granulation tissue curettage, and LPRF use as adjuvant to treatment.

The most commonly used drugs were Alendronate, Zoledronate, Bisphosphonates and Denosumab, with a treatment span of 2 to 10 years, and only two studies were of 6 to 8 months. Of the 14 studies, in the groups that used PRF or L-PRF in the treatment, 11 studies had a 100\% total resolution index, 1 study had $93 \%$, and 1 had a $77 \%$ brief total closure and $18 \%$ late closure, and 1 had $88 \% \mathrm{~L}-\mathrm{PRF}$ and $96.7 \%$ with L-PRF + BPM2. In one of the studies, statistical analysis revealed $\mathrm{p}<0.05$ in elimination of infection and rapid healing of the mucous membranes.

The publications related to the present literature review were published from 2013 to 2018, there was a predominance of studies in 2016 with six studies, 2013 with one study, 2014 with three studies, 2017 with two studies, and 2018 with 2 studies, in a total of 14 studies.

\section{Discussions}

After careful consideration of the literature, it is observed that the risk of developing osteonecrosis of the mandible and its terrible consequences is still neglected by many physicians who use bisphosphonates to combat osteoporosis, as well as by dentists, who, for the most part, of the results of therapeutic failures when performing dental implants, especially in the elderly patient population ${ }^{8-10}$. Elderly patients and menopausal women who are more likely to have osteoporosis are not only affected by osteoporosis but also associated with the adverse effects of bisphosphonates, even in calcium replacement, demineralization ${ }^{17-9}$. In this group of patients, dental implant surgeries may not present the expected results, together with the risk of severe dental loss, implant losses, infections and other harmful consequences resulting from previously installed or ongoing mandibular necrosis ${ }^{21}$.

The present literature review aimed to catalogue evidence of the efficacy of PRF or L-PRF as adjuvant treatment for MRONJ. A universal protocol for MRONJ treatment is not yet 
clearly defined, so there are several methods used, which makes it difficult to compare the studies proposed so far ${ }^{40-42}$.

The different types of treatments performed in studies reported in the literature to date for MRONJ treatment demonstrate a need for a standardized experimental design to better define the optimal treatment. The greatest concern regarding patients who may develop MRONJ is to maintain good oral hygiene, to perform dental treatments prior to the use of ant reabsorbing drugs, to maintain the quality of life of the patient, to control pain and infection, and to prevent the appearance of new areas of necrosis $6,20,39$.

However, the use of L-PRF is a new, non-invasive and rapid alternative approach to managing bone exposure. L-PRF has been used as adjuvant therapy in the treatment of osteonecrosis which allows natural coagulation process ${ }^{43}$.

The results appear to be promising when compared to other techniques previously described as adjuvant to surgical therapy in stages II and III of the disease, since the surgical procedure can only compromise the outcome and do not present favourable conditions for the definitive end of therapy. L-PRF accelerates the healing of soft tissues, improving epithelial vascularisation and brief closure of the wound ${ }^{41,42}$.

According to the literature, MRONJ is associated with the inhibition of osteoclasts caused by the action of the ant reabsorbing drug, presenting suppression of bone remodeling 40,41 , inhibition of angiogenesis ${ }^{42-45}$ and direct toxicity in the buccal mucosa, being a hypothesis of path physiology of the disease $\mathrm{e}^{45-48}$.

The present literature review had several limitations, especially a reduced number of randomized studies ${ }^{49-51}$. Amongst other limitations, $50 \%$ of the studies had small samples, consisting of one to two patients, two studies were comparative and two studies had a series of control patients ${ }^{52,53}$.

Because of the relatively recent pathology, when comparing bisphosphonates, calcium supply and replacement hormone therapy in the fight against osteoporosis and its comorbidities $^{4-5}$. The present research presents some limitations on the quality of studies found and selected on the topic discussed, since most of them are non-randomized studies, with a reduced sample of patients, some of which are summarized only in case of reports, without peer selection or review, that is, with critical methodological biases $^{43-47}$. However, the authors of this essay concluded that this type of discussion should be carried out to draw the attention of the scientific community to a severe health problem, still under diagnosed and therefore underreported ${ }^{21-23}$. Many professionals do not wish to publish their failures, and that in a very next, due to the aging of the world population can affect thousands of people who are included in the clinical characteristics addressed in this research. In addition to a social character, the other important objective of the present study was to alert multiprofessional health teams to the rational use of these drugs, associated with active surveillance and, therefore, notification of this type of condition when it is digested ${ }^{35-37}$. Therefore, those other patients are not suffering or are surprised by therapeutic failures and severe health damages resulting from the consequent jaw necrosis ${ }^{1,2,49-51}$.
It has been observed that up to the present moment, there are not many studies in the relevant literature reporting the efficacy of PRF as a therapy for the treatment and prevention of MRONJ in patients taking osteoporosis medication, such as bisphosphonates and the likes ${ }^{18}$, most likely due to the fact that it is a recent illness and its proposed therapy is a rather new technology 54,55 .

\section{Conclusion}

The use of L-PRF showed an expressive influence on the complete wound healing in short postoperative periods and in the resolution of treatments, drastically reducing the need for postoperative re-interventions, resulting in lower morbidity for patients. As they are presently commonly prescribed drugs, it is of great importance that the Dentist is aware when surgical interventions are necessary in patients who have or still use Bisphosphonates.

Based on the literature review and in the cases studied in the articles, it was concluded that L-PRF is considered a safe, fast and effective alternative method for the treatment of MRONJ. Further randomized and adequately planned controlled clinical trials with larger samples of the use of L-PRF in the treatment of MRONJ are necessary to confirm the effectiveness of the proposed treatment.

\section{Conflict of interest statement}

Maria Faria, Eric Cabral, Wilkson Castro, Davidson Florentino, João Costa, Ricardo Pires, Fausto Guzen, -Francisco Pinheiro, Amália Rêgo and Irami Filho declare that they have no conflict of interest.

\section{References}

[1] Wells GA, Cranney A, Peterson J, Boucher M, Shea B, Robinson V, Coyle D, Tugwell P. Alendronate for the primary and secondary prevention of osteoporotic fractures in postmenopausal women. Cochrane Database Syst Rev. 2008 Jan 23;(1):CD001155.

[2] Ruggiero SL, Woo SB. Biophosponate-related osteonecrosis of the jaws. Dent Clin North Am 2008; 52(1):111-28.

[3] Migliorati CA, Schubert MM, Peterson DE, Seneda LM. Bisphosphonate-associated osteonecrosis of mandibular and maxillary bone: an emerging oral complication of supportive cancer therapy. Cancer 2005; 104(1):83-93.

[4] Otto S, Schreyer C, Hafner S, Mast G, Ehrenfeld M, Stürzenbaum $S$, et al. Bisphosphonate-related osteonecrosis of the jaw- characteristics, risk factors, clinical features, localization and impact on oncological treatment. J Cranio. Maxillo Fac. Surg June 2012; 40(4): 303-9.

[5] Khosla S, Burr D, Cauley J, Dempster DW, Ebeling PR, Felsenberg PR, et al. Biphosphonate-associated osteonecrosis of the jaw: report of a task force of the American Society for Bone and Mineral Research. J Bone Miner Research 2007; 22: 1479-91.

[6] Marx RE. Pamidronate (Aredia) and Zoledronate (Zometa) induced avascular necrosis of the jaw: a growing epidemic. Journal of oral and Maxillofacial Surgery 2003; 61(9): 1115-1117.

[7] Ruggiero SL. Osteonecrosis of the jaws associated with the use of bisphosphonates: a review of 63 cases. 
Journal of Oral and Maxillofacial Surgery 2004; 62(5): 527-534.

[8] Woo SB, Hellstein JW, Kalmar JR. Systematic review: Bisphosphonates and osteonecrosis of the jaw. Ann Int Med 2006; 144: 753-61.

[9] Capsoni F, Longhi M, Weinstein R. Bisphosphonateassociated osteonecrosis of the jaw: the rheumatologist's role. Arthritis Research \& Therapy 2006; 8: 219.

[10] Migliorati CA, Siegel MA, ELTING LS Bisphosphonateassociated osteonecrosis: a long-term complication of bisphosphonate treatment. The Lancet Oncology 2006; 7(6): 508-514.

[11] Khan A. Bisphosphonate-associated osteonecrosis of the jaw. Canadian Family Physician 2008; 54(7): 10191021.

[12] Pazianas M, Blumentals WQ, Miller PD. Lack of association between oral bisphosphonates and osteonecrosis using jaw surgery as a surrotgate marker. Osteoporos Int 2008; 19: 773-9.

[13] Ruggiero SL et al. American Association of Oral and Maxillofacial Surgeons Position Paper on Bisphosphonate-Related Osteonecrosis of the Jaws2009 Update. J Oral Maxillofac Surg 2009; 67: 2-12.

[14] AAOMS. American Association of Oral and Maxillofacial Surgeons position paper on bisphosphonate-related osteonecrosis of the jaws. J Oral Maxillofac Surg 2007; 65(3): 369-76.

[15] Ruggiero SL, Drew SJ. Osteonecrosis of the jaws and bisphosphonate therapy. J Dent Res. 2007 Nov;86(11):1013-21.

[16] Kobayashi Y, Ueda A, et al. Zoledronic acid delays wound healing of the tooth extraction socket, inhibits oral epithelial cell migration, and promotes proliferation and adhesion to hydroxyapatite of oral bacteria, without causing osteonecrosis of the jaw, in mice. Journal of Bone and Mineral Metabolism 2009; 28(2): 165-175.

[17] Asaka T, Ohga N, Yamazaki Y, Sato J, Satoh C, Kitagawa Y. Platelet-rich fibrin may reduce the risk of delayed recovery in tooth-extracted patients undergoing oral bisphosphonate therapy: a trial study. Clin Oral Invest 2017; 21(7): 2165-2172.

[18] Société Française de Stomatologie, Chirurgie MaxilloFaciale et Chirurgie Orale Ostéonécrose des mâchoires en chirurgie oromaxillofaciale et traitements médicamenteux à risque (antirésorbeurs osseux, antiangiogéniques) Recommandations de Bonne Pratique Juillet. 2013.

[19] Rupel K, Ottaviani G, Gobbo M, Contardo L, Tirelli G, Vescovi P, et al. A systematic review of therapeutical approaches in bidphosphonates-related osteonecrosis of the jaw (BRONJ). Oral Oncology 2014; 50: 10491057.

[20] Lopez PJ, Perez AS, Mendes RA, Tobias A. Medicationrelated osteonecrosis of the jaw: Is autologous platelet concentrate application effective for prevention and treatment? A systematic review. Journal of CranioMaxillofacial Surgery Aug 2016; 44(8): 1067-72.
[21] Lerman MA, Xie W, Treister NS, RichardsonI PG, Weller EA, Woo S-B. Conservative management of bisphosphonate-related osteonecrosis of the jaws: Staging and treatment outcomes Oral Oncology 2013; 49(9): 977-983.

[22] Giudice A, Barone S, Giudice C, Bennardo F, Fortunato L. Can platelet-rich fibrin improve healing after surgical treatment of medication-related osteonecrosis of the jaw? A pilot study. Oral Surg Oral Med Oral Pathol Oral Radiol. 2018 Nov;126(5):390-403.

[23] Weber JBB, Camilotti RS, Ponte ME. Efficacy of laser therapy in the management of bisphosphonate-related osteonecrosis of the jaw (BRONJ): a systematic review. Lasers in Medical Science 2016; 31(6): 1261-1272.

[24] Marx RE, Carlson ER, EichstaedtI RM, Schimmele SR, Strauss JE, Georgeff KR Platelet-rich plasma: growth factor enhancement for bone grafts. Oral Surg Oral Med Oral Pathol Oral Radiol Endod Jun1998; 85: 638-646.

[25] Del Fabbro M, Gallesio G, Mozzati M. Autologous platelet concentrates for bisphosphonate-related osteonecrosis of the jaw treatment and prevention. A systematic review of the literature. Eur J Cancer 2015; 51(1): 62-74.

[26] Soydan SS, Uckan S. Management of bisphosphonaterelated osteonecrosis of the jaw with a platelet-rich fibrin membrane: technical report. J Oral Maxillofac Surg 2014; 72(2): 322-326.

[27] Kim JW, Kim SJ, Kim MR. Leucocyte-rich and plateletrich fibrin for the treatment of bisphosphonate-related osteonecrosis of the jaw: a prospective feasibility study. Br J Oral Maxillofac Surg 2014; 52(9): 854-859.

[28] Curi MM, Cossolin GSI, Koga DH, Zardetto C, Christianini S, Feher O, et al. Bisphosphonate-related osteonecrosis of the jaws-an initial case series report of treatment combining partial bone resection and autologous platelet-rich plasma. J. Oral Maxillofac Surg 2011; 69: 2465-72.

[29] Bocanera-Perez S, Vicente-Barreiro M, Knezevic M, Castellano-Navarro JM, Rodrígues-Bocanegra E, Rodrígues-Millares J et al. Use of platelet-rich plasma in the treatment of bisphosphonate-related osteonecrosis of the jaw. Int J Oral Maxillofacial Surg 2012; 41: 14105.

[30] Mozzati M, Gallesio G, Arata V, Pol R, Scoletta M. Platelet-rich therapies in the treatment of intravenous bisphosphonates-related osteonecrosis of the jaw: a report of 32 cases. Oral Oncol 2012; 48: 469-74.

[31] Choukroun J; Adda F; Schoeffer C, Vervelle A. PRF: an opportunity in perio-implantology (in French). Implantodontie 2000; 42: 55-62.

[32] Choukroun J, Diss A, Simonpieri A, et al. Platelet-rich fibrin (PRF): a second-generation platelet concentrate. Part IV: clinical effects on tissue healing. Oral Surg Oral Med Oral Pathol Oral Radiol Endod 2006; 101: 56.

[33] Dohan EDM, Rasmusson L, Albrektsson T. Classification of platelet concentrates: From pure platelet-rich plasma (P-PRF) to leucocyte-and platelet-rich fibrin (LPRF). Trends Biotechnol 2009; 27: 158. 
[34] Dohan DM, Choukroun J, Diss A, Dohan SL, Dohan AJJ, Mouhyi J, et al: Plateletrich fibrin (PRF): A secondgeneration platelet concentrate. Part III: leucocyte activation: A new feature for platelet concentrate? Oral Surg Oral Med Oral Pathol Oral Radiol Endod 2006; 101: e51.

[35] Ling H, Ye L, Xiulian H, Yu Z, Hui W. A comparative study of platelet-rich fibrin (PRF) and platelet-rich plasma (PRP) on the effect of proliferation and differentiation of rat vosteoblasts in vitro. Oral Surg Oral Med Oral Pathol Oral Radiol Endod 2009; 108: 707.

[36] Everts PAM, Zundert A, Schonberger JPAM, Devilee RJJ. What do we use: platelet-rich plasma or plateletleukocyte gel? J Biomed Mater Res A 2008; 85: 1135-6.

[37] Werther K, Christensen IJ, Nielson HJ. Determination of vascular endothelial growth factor (VEGF) in circulating blood: significance of VEGF in various leucocytes and plateles. Scand J Clin lab Invest 2002; 62: 343-50.

[38] Kuhl S, Walter C, Acham S, et al. Bisphosphonaterelated osteonecrosis of the jaw-a review. Oral Oncology 2012; 48: 938-947.

[39] Subramanian G, Cohen HV, Quek SY: A model for the pathogenesis of bisphosphonate-associated osteonecrosis of the jaw and teriparatide's potencial role in its resolution. Oral Surgery Oral Medicine Oral Pathology Oral Radiology and Endodontology 2011; 112: 744.

[40] Reid IR, Cornish J: Epidemiology and pathogenesis of osteonecrosis of the jaw. Nature Reviews Rheumatology 2012; 8: 90.

Develo

[41] Santini D, Vincenzi B, Dicuonzo G, Avvisati G, Massacesi C, Battistoni F, et al. Zoledronic acid induces significant and long-lasting modifications of circulating angiogenic factors in cancer patients. Clinical Cancer Research 2003; 9: 2893.

[42] Fournier P, Boissier S, Filleur S, Guglielmi J, Cabon F, Colombel M, et al. Bisphosphonate inhibit angiogenesis in vitro and testosterone-stimulated vascular regrowth in the ventral prostate in castrated rats. Cancer research 2002; 62: 6538.

[43] Reid IR, Bolland MJ, Grey AB. Is bisphosphonateassociated osteonecrosis of the jaw caused by soft tissue toxicity? Bone 2007; 41: 318.

[44] Mozzati M, Martinasso G, Maggiora M, Scoletta M, Zambeli M, Carossa S, et al. Oral mucosa produces cytokines and factors influencing osteoclast activity and endothelial cell proliferation, in patients with osteonecrosis of the jaw after treatment with zoledronic acid. Clinical Oral Investigations 2013; 17: 1259.
[45] Jadad AR, Moore RA, Carroll D, Jenkinson C, Reynolds DJ, Gavaghan DJ, et al. Assessing the quality of reports of randomized clinical trials: is blinding necessary? Control Clin Trials [Internet]. 1996 Feb;17(1):1-12.

[46] Dincâ O, Zurac B, Stâniceanu F, Bucur MB, Bodnar DC, Vlâdan C, et al. Clinical and histopathological studies using fibrin-rich plasma in the treatment of bisphosphonate-related osteonecrosis of the jaw: Case Reports. Rom J Morphol Embryol 2014; 55(3): 961964.

[47] Gõnem ZB, Yilmaz AC. Treatment of bisphosphonaterelated osteonecrosis of the jaw using platelet-rich fibrin. J Craniomandib \& Sleep Pract 2017; 35(5): 332336.

[48] Park JH, Kim JW, Kim SJ. Does the Addition of Bone Morphogenetic Protein 2 to Platelet Rich Fibrin Improve Healing After Treatment for MedicationRelated Osteonecrosis of the Jaw? J Oral Maxillofac Surg 2016; 75(6): 1176-1184.

[49] Nørholt SE, Hartlev J. Surgical treatment of osteonecrosis of the jaw with the use of platelet-rich fibrin: a prospective study of 15 patients. Int J Oral Maxillofac Surg 2016; 45(10): 1256-1260.

[50] Maluf G, Pinho MC, Cunha SRB, Santos PSS, Fregnani ER. Surgery Combined with LPRF in Denosumab Osteonecrosis of the Jaw: Case Report. Braz Dent J 2016; 27: 353-8.

[51] Inchingolo F, Cantore S, DipalmaI G, Georgakopoulos I, Almasri M, Cheno E et al. Platelet rich fibrin in the management of medication-related osteonecrosis of the jaw: a clinical and histopathological evaluation. J Biol Regul Homeost Agents 2017; 31(3): 811-816.

[52] Kim JW, Kim SJ, Kim MR. Simultaneous Application of Bone Morphogenetic Protein-2 and Platelet-Rich Fibrin for the Treatment of Bisphosphonate-Related Osteonecrosis of Jaw. J Oral Implantol 2016; 42(2): 205-8.

[53] Maluf G, Caldas RJ, Santos PSS. Use of Leukocyte-and Platelet-Rich Fibrin in the Treatment of MedicationRelated Osteonecrosis of the Jaws. J Oral Maxillofac Surg 2018; 76: 88-96.

[54] Tsai LO-Lin, Huang YU-Feng, Chang YU-Chao. Treatment of bisphosphonate-related osteonecrosis of the jaw using platelet-rich fibrin. Journal of the Formosan Medical Association, 2015.

[55] Pelaz A, Junquera L, Gallego L, García-Consuegra L, Junquera S, Gómez C. Alternative treatments for oral bisphosphonate-related osteonecrosis of the jaws: A pilot study comparing fibrin rich in growth factors and teriparatide. Med Oral Patol Oral Cir Bucal Jul 2014; 19(4): 320-6. 
International Journal of Trend in Scientific Research and Development (IJTSRD) @ www.ijtsrd.com eISSN: 2456-6470

\begin{tabular}{|c|c|c|c|c|c|c|c|}
\hline ITEMS & $\begin{array}{l}\text { Asaka et } \\
\text { al }^{17} 2016\end{array}$ & $\begin{array}{l}\text { Giudice et } \\
\text { al }^{22} 2018\end{array}$ & $\begin{array}{l}\text { Soydan et } \\
\text { al }^{26} 2013\end{array}$ & $\begin{array}{c}\text { Kim et } \\
\text { al }^{27} \\
2014\end{array}$ & $\begin{array}{l}\text { Dinca et } \\
\text { al }^{46} \\
2014\end{array}$ & $\begin{array}{l}\text { Gönen et } \\
\text { al }{ }^{47} \\
2017\end{array}$ & $\begin{array}{c}\text { Park et } \\
\text { al } 48 \\
2017\end{array}$ \\
\hline $\begin{array}{l}\text { Was the study described as } \\
\text { randomized? }\end{array}$ & No & Yes & No & No & No & No & No \\
\hline $\begin{array}{c}\text { Was the study described as } \\
\text { double-blind? }\end{array}$ & No & No & No & No & No & No & No \\
\hline $\begin{array}{l}\text { Was there a description of } \\
\text { withdrawals and dropouts? }\end{array}$ & Yes & Yes & No & Yes & Yes & No & Yes \\
\hline $\begin{array}{c}\text { Was the method for } \\
\text { generating the randomization } \\
\text { sequence described and } \\
\text { appropriate? }\end{array}$ & No & Yes & No & No & No & No & No \\
\hline $\begin{array}{l}\text { Was the double-blind method } \\
\text { described and appropriate? }\end{array}$ & No & No & No & No & No & No & No \\
\hline SCORE & 1 & 3 & $\mathbf{0}$ & 1 & 1 & $\mathbf{0}$ & 1 \\
\hline ITEMS & $\begin{array}{c}\text { Norholt } \\
\text { et al. } 49 \\
2016 \\
\end{array}$ & $\begin{array}{c}\text { Maluf et } \\
\text { al. } 50 \\
2016 \\
\end{array}$ & $\begin{array}{c}\text { Inchingolo } \\
\text { et al } 51 \\
2017 \\
\end{array}$ & $\begin{array}{c}\text { Kim et } \\
\text { al } 52 \\
2016 \\
\end{array}$ & $\begin{array}{c}\text { Maluf et } \\
\text { al } 53 \\
2018 \\
\end{array}$ & $\begin{array}{c}\text { Tsai et al } \\
54 \\
2016 \\
\end{array}$ & $\begin{array}{c}\text { Pelaz A } \\
\text { et al55 } \\
2014 \\
\end{array}$ \\
\hline $\begin{array}{l}\text { Was the study described as } \\
\text { randomized? }\end{array}$ & No & No & No & No & No & No & No \\
\hline $\begin{array}{c}\text { Was the study described as } \\
\text { double-blind? }\end{array}$ & No & No & No & No & No & No & No \\
\hline $\begin{array}{l}\text { Was there a description of } \\
\text { withdrawals and dropouts? }\end{array}$ & Yes & & & No & No & No & Yes \\
\hline $\begin{array}{c}\text { Was the method for } \\
\text { generating the randomization } \\
\text { sequence described and } \\
\text { appropriate? }\end{array}$ & & & & & No & No & No \\
\hline $\begin{array}{l}\text { Was the double-blind method } \\
\text { described and appropriate? }\end{array}$ & No & No & $\mathrm{No}$ & Jo & No & No & No \\
\hline SCORE & 1 & $\mathbf{0}$ & 1 & 0 & $\mathbf{0}$ & $\mathbf{0}$ & 1 \\
\hline
\end{tabular}

Table1. Assessing the Quality of Reports of Clinical Trials with Jadad scale45

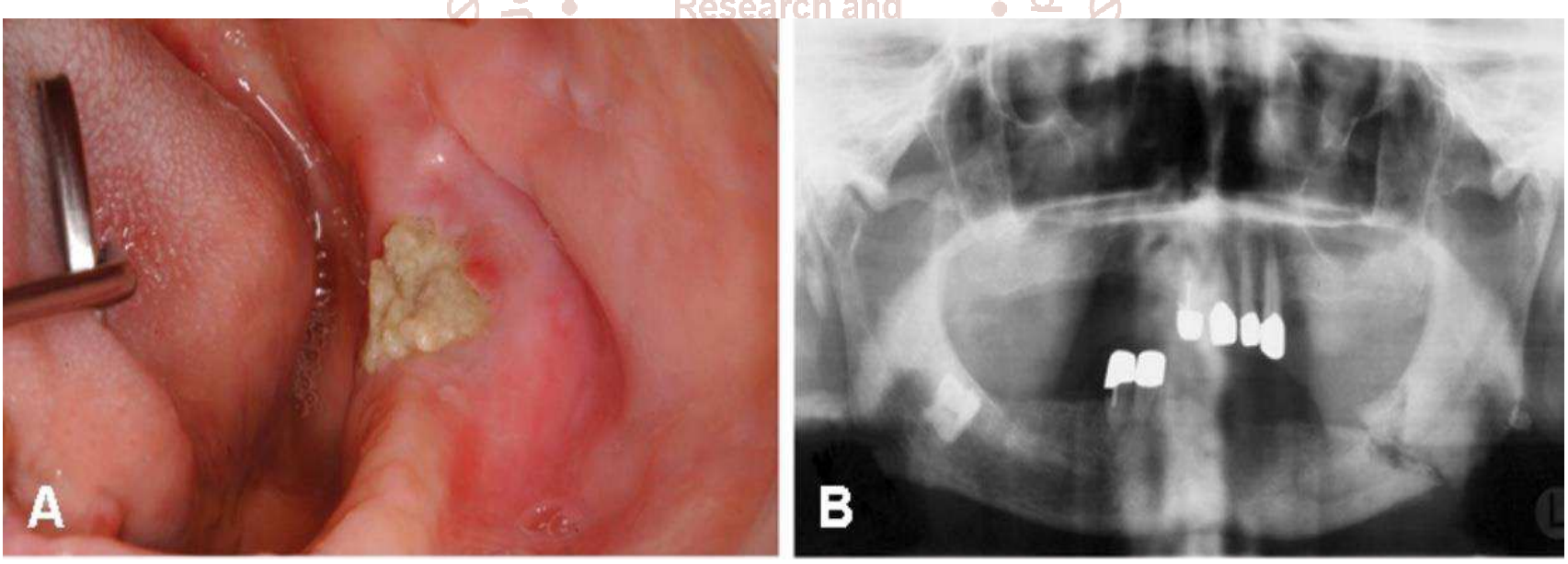

Figure1. (A) Intraoral view with exposure to the necrotic bone in the left jaw angle; (B) panoramic radiograph Preoperatively identifying the fractured mandible angle. MORRISON A. PathologyOutlines.com 2018 http://pathologyoutlines.com/topic/mandiblemaxillaMRONJ.html. Accessed September 4th, 2018 